\title{
Megjegyzések a magyar regionális tudomány aktuális kihívásaihoz
}

\author{
Remarks on the current challenges of Hungarian \\ regional science \\ RÁCZ SZILÁRD
}

\begin{abstract}
RÁCZ Szilárd: tudományos munkatárs, Közgazdaság- és Regionális Tudományi Kutatóközpont, Regionális Kutatások Intézete; 7621 Pécs, Papnövelde u. 22.; szracz@rkk.hu; https://orcid.org/0000-0002-9397-2620
\end{abstract}

KULCSSZAVAK: regionális tudomány; tudományos stratégia; tudománypolitika

Szilárd RÁCZ: research fellow, Institute for Regional Studies, Centre for Economic and Regional Studies; Papnövelde u. 22., H-7621 Pécs, Hungary; szracz@rkk.hu; https://orcid.org/0000-00029397-2620

KEYWORDS: regional science; research strategy; science policy

Kiindulásképpen szeretném leszögezni, hogy mind az elkészült tanulmányt (Lengyel Imre, Nemes Nagy József, Rechnitzer János, Varga Attila: A hazai regionális tudományról - eredmények és kihívások), mind annak a köztestületi tagokkal közös megvitatását fontos és előremutató kezdeményezésnek tartom. Köszönet illeti azokat, akik a nyíltság és az őszinteség útját választották a magyar regionális tudomány helyzetének, jövőjének átgondolásához. Úgy gondolom, ez az, ami a közösségünk kohézióját hosszú távon szolgálja.

Terjedelmi okokból csak néhány konkrét kihívás, javaslat megfogalmazására reagálnék, amire mások nem térnek ki hozzászólásuk írott verziójában.

A hazai regionális műhelyek „töredezettségének” alapvetően személyi okai vannak, a kutatások „,koordinálatlansága” e tekintetben egy vezéregyéniség, illetve egy kvázi monopolhelyzetű szervezet hiányának tudható be. Ez nem feltétlenül probléma, talán kívánatos is, hiszen lehetőséget ad a decentralizált fejlödésre. Kiépültek hivatalos fórumok - ahol minden fontos szereplő az asztalnál ül -, és általánosságban véve a magyar regionális tudományi műhelyek vezetői jó személyes kapcsolatokat ápolnak egymással - vagyis mindenki szóba áll mindenkivel -, ez az örökség, adottság jó alapot ad a közös gondolkodásra és a stratégiai együttmúködésre.

A generációváltás, a tudományos utánpótlás esetében az MTA doktora cím „helyzete” alapvető fontosságú. Nagy érdem, hogy a Regionális Tudományi Bizottságnak (RTB) önálló doktoráltatási joga van, e jog megőrzése mindannyiunk érdeke. A követelményrendszer tovagyűrüző hatásaira érdemes fokozott figyelemmel

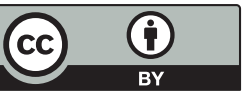


lenni. Az egyéni, szervezeti eredményesség mérése (akár korábbi munkák, életművek megítélése), a kutatási pályázatok sikere, a minősítések ( $\mathrm{PhD}$, habilitáció, egyetemi tanári) elnyerése függ a publikációkkal kapcsolatos elvárásoktól. Elönyös, hogy a MTA doktori követelmény nem „mozgó célpont”, ha a legfontosabb kritériumok hosszú távon rögzítettek, akkor elérésükre fel lehet készülni, a kutatói életpálya ezen eleme kiszámíthatóbb, tervezhetőbb. Azonban a közeljövőben átgondolandó, vajon indokolt-e, hogy az RTB saját (tehát a bizottság által megváltoztatható), a doktori folyamat elindításának támogatásához szükséges minimumkövetelményei legyenek a legmagasabbak a IX. Osztályon (az értékelési táblázat szerint az RTB hét pótlólagos „tüzes karikát” állít a pályázók elé).

A regionális tudomány nyitottságának eredménye, hogy az elmúlt évtizedben jelentősen megnőtt a tömegbázisa. A diszciplináris és tematikai sokszínűség, a kedvező korstruktúra - sok doktori előtt álló fiatal - csak részben oka annak, hogy az RTB jelenlegi 169 köztestületi tagja és a Magyar Regionális Tudományi Társaság (MRTT) 219 aktív tagja között alig 82 fö az átfedés. Ha ehhez hozzávesszük a mintegy 130 regionális PhD-fokozatot szerzett kollégát, akkor láthatjuk a kutatói pálya vonzerejének vagy éppen a regionalista identitás leértékelődését a fiatal posztdoktorok esetén (a három lista közötti átfedés kevesebb, mint 40 fó). Értelmezhetjük azonban ezt a jelenséget úgy is, hogy van még tartalék, perspektíva az RTB-tagok számát tekintve. Most sem áll rosszul a bizottság, a köztestületi tagok számát tekintve az MTA bizottságai között még éppen befér az első harmadba. Természetesen a kevésbé aktív tagok megszólítása is éppúgy fontos teendő, mint a bázis szélesítése. Érdemes a köztestületi körön kívül is gondolkodni, például az MTA területi bizottságaiban folyó testületi munka keretében.

Megfontolandó javaslat az önkéntes kutatásnyilvántartási rendszer létrehozása, megfelelően szervezett információáramlással. Ehhez a publikációk esetében kiváló alapot adhat az RKI-ELEKTRA repozitórium, amely a magyar regionális tudomány elektronikus archívumává fejleszthető. A Regionális Kutatások Intézete emellett még számos értékkel bír jelenlegi állapotában is - titkárként kiemelném, hogy biztos hátteret nyújt az MRTT hatékony müködéséhez -, ezért egyetértek azzal és egyúttal köszönöm, hogy a vitaanyag szerzői kiállnak az RKI mellett.

Dicsérendő a záró következtetés, az optimizmusra okot adó, „megfelelő helyre" került érdemes fiatalok. A fiatalabb kutatók hozzászólásai a vitaanyaghoz megerősítették Buday-Sántha Attila professzor mondását: „Mindenkiben rejlik valamilyen tehetség, ezt kell megtalálni és erre koncentrálni." Ehhez annyit tennék hozzá, hogy a magyar regionális tudomány missziójának megvalósításához, örökségének ápolásához, a tehetség kibontakozásához elengedhetetlen valamilyen szintü támogató környezet. 